\title{
A Contrastive Study of English and Igala Segmental Phonemes: Implications for ESL Teachers and Learners
}

\author{
Unubi, Sunday Abraham \\ Department of English and Literary Studies, Kogi State University, Anyigba, Nigeria \\ unubi4u@gmail.com
}

\begin{abstract}
This paper investigated a contrastive study of English and Igala segmental phonemes: implications for English as a Foreign Language (EFL) teachers and learners. A contrastive analysis is a linguistic tool used in comparing two unrelated languages, and the main objective of it is to bring out the differences in the two languages compared with a view to emphasising on the effects which such differences have on both EFL teachers and learners. This research appealed only to the secondary sources of data, which included the orthographies of both languages under study. The Igala orthography was obtained from the department of Igala Language and Culture, Kogi State College of Education Ankpa, in addition to other material in Igala. The consonant and vowel phonemes of the two languages were placed contiguously in a tabular form and given appropriate heading to be able to observe their level of differences and similarities easily. Then words in which these phonemes occur in the Igala language were supplied and the phonemes indicated. Some of the findings of this research revealed the following: (i) that the consonant phonemes such as / $\delta /$, $/ \theta /, / \mathrm{s} /, / \mathrm{s} /, / 3 /, / \mathrm{v} /$ and $/ \mathrm{z} /$, and the vowel phonemes $/ \partial /$ and $/ \Lambda /$, which are present in English are however absent in Igala, just as /kp/, /gb/, /ny/, /kw/, /gw/ and /nw/ that are present in Igala are absent in English; (ii) English has twelve pure vowels (monophthongs) and eight diphthongs, while Igala has fourteen monophthongs and eleven diphthongs; (iii) that these differences have posed certain teaching and learning difficulties to both EFL teachers and learners who are native speakers of the Igala language; and (iv) that while English has twenty-four consonant phonemes, Igala has twenty-three.
\end{abstract}

Key words: contrastive study, English, Igala, segment, phoneme, ESL teachers and learners.

\section{Introduction}

This paper explores a contrastive study of English and Igala segmental phonemes: implications for English as a Foreign Language (ESL) teachers and learners. The segmental phonemes under study constitute the orthography - the tool for writing a language, which are basically divided into two parts: consonants and vowels. These are symbols or letters that represent the sounds of a language. It is these sounds that combine to supply words, phrases, clauses or sentences in a language. In this study, the sole concern of the researcher is present the segmental phonemes of both languages contiguously with a view to determining their level of differences. And indeed, such differences will be taken into cognizance as well as how they pose teaching and learning difficulties to EFL teachers and learners. 
Wilton [2001] as cited in Unubi [2018:6] reports that the English language belongs to the West Germanic branch of the Indo-European family of languages. This broad family includes most of the European languages spoken today. English was spoken first in England about 1,500 years ago but it was in existence before then. The English language has its origin in north-western Germany, from where it was brought to England by the Anglo-Saxons. At the time this happened, approximately 1,500-1,600 years ago, English was very different from what it is today, in grammar, vocabulary and pronunciation. This difference is indicated by the use of the expression 'Old English' (or, sometimes, 'Anglo-Saxon') to refer to the earlier form of the language. Since then, Old English has evolved into the language of today. Geographically, Unubi \& Bello [2019:60] mention that the English language was confined to 'the British Isles', a group of Islands lying off the north-west coast of the continent of Europe in the northern temperate zone of the world. Furthermore, there are two main islands, namely Britain, the larger of the two, and Ireland, the smaller. Politically too, the British Isles today also comprises two main parts, namely the United Kingdom of Great Britain and Northern Ireland, made up of England, Wales, Scotland (i.e. Britain), and Northern Ireland, with its capital at London; and the Republic of Ireland, with its capital at Dublin. This evolution is regarded generally as falling into three main stages or periods, as follows: Old English: 500 to about 1100 AD; Middle English: about 1100 - 1500 AD; and Modern English: 1500 - present day.

Igala is a language of the Yoruboid branch of the Defoid family, a sub-group of Benue-Congo family of Kwa family, which belongs to the larger group of the Niger-Congo family, according to the tree of the family of languages. The Yoruboid branch comprises the Yoruba, the Igala and the Itsekiri groups of south-western Nigeria. Unubi \& Yusuf [2017:411] quote Egbunu [2005] as saying that Igala land is demographically located within the triangle formed by the confluence of the Rivers Niger and Benue. The Igala people are found east of the confluence of these rivers. The land is bounded on the west by River Niger, on the east by Enugu State, the south by Anambra State and on the north by Benue and Nassarawa States. It is 120 kilometres wide and 160 kilometres long. It is located approximately between latitudes $6^{\prime} 80^{\circ}$ and $8^{\prime}$ north and longitudes $6^{\prime} 30^{\circ}$ and $7^{\prime} 40^{\circ}$ east and covers an area of about 13,665 square kilometres. As noted by Edimeh [2006:5], Igala land is mostly rural but urbanisation has gradually set in. The major centres of population include Idah, Ejule, Anyigba, Egwume, Dekina, Okpo and Abejukolo. Culturally, the central geographical location of the Igala people has exposed them to a wide variety of linguistic as well as cultural influences from other ethnic groups in the country. Notable among these are the Ebira, the Bini, the Igbo, the Hausa, the Idoma and the Yoruba ethnic groups. The Igala people occupy the Eastern Senatorial District of Kogi State, and out of the twenty-one Local Government Areas of the State, Igala has nine.

\section{Statement of the Research Problem}

Over the years, a reasonable number of researches or studies on different aspects of Igala phonetics and phonology have been carried out. However, as far as the discipline of linguistics is concerned, contrastive studies in which English and Igala segmental phonemes are placed side by side with a view to determining their differences as well as stating categorically the implications of such differences on ESL teachers and learners are not common. This research, therefore, is primarily thought of by the researcher to fill this obvious gap or vacuum in the study of the Igala language. Secondarily, apart from the three major Nigerian languages, a good number of researches, though may not include all levels of linguistic study, no doubt, have been conducted in a good number of small group languages. It is also without doubt that many others have been under-researched. In view of this, this study has been embarked upon by the researcher 
Unubi, Sunday Abraham; A Contrastive Study of English and Igala Segmental Phonemes: Implications for ESL Teachers and Learners. Journal of Biomedical Engineering and Medical Imaging, Volume 6, No 6, December (2019), pp 31-43

in order to present it to the readership (both scholars and students) as a template for those who wish to carry out similar studies in other small group indigenous languages of Nigeria.

\section{Literature Review}

Our review of literature here will concentrate mainly on the important concepts that constitute the topic or title of this research, which are contrastive study, segment, phoneme, ESL learners and teachers. It will also include empirical review of works done previously by other scholars that are related to the current study.

\subsection{Conceptual Review}

\subsubsection{Contrastive Analysis}

Historically, Kopečna [2008:3] reports that after the Second World War in 1945, the interest in teaching foreign languages increased in the USA and many linguists were concerned with pedagogically oriented contrastive studies, especially in trying to predict learning difficulties on the basis of comparing the native language with the foreign language being learnt, and also with the study of bilingualism and language contact phenomena. Therefore, a contrastive study is a kind of study that deals with the comparison of two languages: learners' target language and learners' native language, and this is usually done by looking at the structural similarities and differences of the two languages under study. In other words, a contrastive study actually means the comparison of two languages by paying attention to differences and similarities between the languages being compared. According to James [1980:2-3], a contrastive study is a linguistic enterprise aimed at producing inverted (that is, contrastive, not comparative) two-valued typologies (a contrastive study is always concerned with a pair of languages). It is not concerned with classification because the term contrastive implies more interest in differences between languages than in their likenesses. Contrastive study is founded on the assumption that languages can be compared. Moreover, Johansson [2008] as cited in Unubi [2018:36] defines contrastive study as the systematic comparison of two or more languages, with the aim of describing their similarities and differences, and it has often been done for practical or pedagogical purposes. He further states that there is more to contrastive study than this, and that is, when we compare two languages, we often see things more clearly.

\subsubsection{Segment}

The word segmental is an adjective derived from the noun segment. As a result, our review here shall be on the phonological term segment, instead of segmental. Crystal [1991:308] declares that a segment in linguistics is any discrete unit that can be identified, either physically or auditorily, in the stream of speech. In other words, a segment in speech is any one of the discrete units that occur in a sequence of sounds, which can be broken down into phonemes, syllables or words through a process called speech segmentation. Segments are called discrete because they are separate and individual, such as consonants and vowels, and occur in a distinct temporal order. In a related development, Szczegielniak [2001:2] defines segment as a continuous stream of speech into distinct parts, which are recognisable in other words. Going further, he stresses that anyone who knows a language knows how to segment sentences into words and words into sounds. In his own view, Roach maintains:

"When we analyse an utterance, we can identify a number of phonological and grammatical elements, partly as a result of our knowledge of the language. Consequently, we are able to write down something 
we hear in words separated by spaces, and (with proper training) transcribe with phonemic symbols the sounds that we hear. However, when we examine speech sounds in connected speech closely, we find many cases where it is difficult to identify separate sound units (segments) that correspond to phonemes since many of the articulatory movements that create the sounds tend to be continuous rather than sharply switched. As a result, some people believe that dividing speech up into segments (segmentation) is fundamentally misguided; the opposite view is that since segmentation appears to be possible in most cases, and speakers seem to be aware of segments in their speech, we should not reject segmentation because there are problematical cases" [Roach, 2009:76].

\subsubsection{Phoneme}

The word phoneme, as revealed by Moore [2001:3] originates from the Greek word phonema, which means a sound. Therefore, a phoneme is a speech sound. In other words, it is the smallest unit of sound that distinguishes one word from another. Since sounds cannot be written, we use letters or symbols to represent or stand for the sounds. Such letters or symbols are called phonemes. As noted by Dresher [2008:243]: "The concept of the phoneme was central to the development of phonological theory. In the early twentieth century, the phonological theory (classical phonemics) was all about the phoneme: how to define it, how to recognise it, and how to discover it". In addition, Bittner [2013:4] asserts that the phoneme is the basic unit of the phonology of a language, which is combined with other phonemes to form meaningful units such as words and morphemes. The phoneme is the smallest unit of language that distinguishes meaning - the organisational unit of phonology, and it is the basic unit of study in phonology, which is a set of phones (sounds) that functions as one unit in a language, and provides contrast between different words. He further states that there are two major views regarding the definition of the phoneme: (i) according to the American structuralist tradition, the phoneme is defined in line with its allophones and environments, and (ii) according to the generative tradition, the phoneme is defined as a set of distinctive features. From the foregoing, the following are true in discussing the phoneme, as thus summarised by the researcher: (i) it is a minimal unit that serves to distinguish between meanings of words; (ii) it is pronounced in one or more ways, depending on the number of allophones; and (iii) it is usually represented or placed between slashes by convention.

\subsubsection{English as a Foreign Language (ESL)}

ESL is an acronym which stands for English as a Second Language. Obviously, according to Aluke (2017:17), English Language is an international language which has penetrated several borders, of which Nigeria is one. This means that it has assumed the role of a global language. It is beyond contention that English as a global language is spoken by some as a first language, many others as a second and an official language like Nigeria, and to a good percentage of others, as a foreign language. Almost every society needs the knowledge of this language for speedy development in this era of technology since it serves as the language of international interaction, diplomacy and business. This language has been accepted by many countries as an official language and the language of learning and instruction in most schools. In Nigeria, English is the most important means of communication. The language is bequeathed to Nigeria by the British colonialists through trade relations and missionary activities, where it has come to stay and performs various functions. English is a lingua-franca in Nigeria, and as such, it is the language of instruction in which teaching and learning takes place. In fact, a student is expected to have at least a credit pass in Ordinary Level English as a requirement for admission into tertiary institutions in the 
Unubi, Sunday Abraham; A Contrastive Study of English and Igala Segmental Phonemes: Implications for ESL Teachers and Learners. Journal of Biomedical Engineering and Medical Imaging, Volume 6, No 6, December (2019), pp 31-43

country. In view of the foregoing, teaching and learning of English in Nigeria has become a sine qua non. So, one who is certified or qualified to teach the English language is referred to as an ESL teacher, while the one who acquires or learns the English language whether formally or informally is regarded as an ESL learner.

\subsection{Empirical Review}

Undoubtedly, studies on a subject such as this have been embarked upon previously in the field of linguistics by other scholars in Nigeria. Some of them which are closely related to the present study are outlined below:

Mugair, Sarab Kadir \& Mahadi, Tengku Sepora Tengku [2014] undertook a research entitled A contrastive analysis of vowel sounds in English and Arabic Languages. The research mainly focused on the comparison between standard American English and standard Arabic which is called Modern Literary Arabic as it is the language of publications in all the Arab states, as well as the oral language of formal occasions. In doing this, the researchers juxtaposed the vowels of English and Arabic and supplied examples from both languages to draw out the similarities and difference. The study also debates the difficulties that Arabs learning English face when learning English. According to this study, the researchers found out that there are similarities and differences in distribution the vowel sounds in both English and Arabic languages. They differ in number; English has more vowels than Arabic, i.e., Arabic has far fewer vowels and diphthongs than English and articulation is more stressed than English. There is also the use of glottal stops before initial vowels. These languages are also different in distribution; English words can start with vowels, whereas Arabic words can only start with consonants. Both languages have several joint vowels, but in the same respect, there are some vowel sounds that are limited to each one of them.

Similarly, Malah, Zubairu \& Rashid, Sebariah Md. [2015] carried out a study titled Contrastive analysis of the segmental phonemes of English and Hausa languages. According to the researchers, the objectives of this study were: (i) to identify the similarities and differences between the segmental phonemes of English and Hausa languages, and (ii) to predict learning difficulties among the Hausa ESL learners based on this comparison. Learners of English as a second language (L2) are usually faced with difficulties largely contributed by the features of their first languages (L1). The Hausa speakers in Nigeria learn English as a second language and features of the Hausa language are heavily evident in their spoken English. As for the data collection for this study, the authors employed desk research where data were drawn from archive and then analyzed side-by-side revealing their similarities and differences. The results of the study demonstrated that although Hausa and English have some similar phonemes, the sounds do not behave the same way in the two languages, and Hausa has 47 phonemes when English has 44 . Differences in the phonological features between the two languages result in challenges faced by the Hausas in learning English.

Furthermore, Nwabudike, Christopher Eziafa; Kaan, Aondover Theophilus \& Anaso, George Nworah [2015] conducted a research entitled A contrastive analysis of English and Tiv segmental phonemes: Implications in ESL Learning. This paper focused on a contrastive analysis of the segmental phonemes of the Tiv and English languages with emphasis on the implication of the differences in the learning of English as a second language by people whose first language is Tiv. The study, according to the researchers revealed that while Tiv language has more consonants than the English language, both languages have the same number of vowels, but Tiv vowels /a/ and /o/ are not found in English, just as English vowels / $/$ / 
and $/ æ /$ are not present in Tiv. And this is the dilemma of the Tiv learner of English language. The work ended with some suggestions on how to eradicate or at least grossly minimize the resultant interference. To this end, the implications of L1 on learning a second language need to be highlighted, especially in respect of segmental phonemes, and this must not be taken for granted so that teachers of English are aware of their responsibilities in the teaching and learning of English as it relates to instructional goals.

Lastly, Unubi, Sunday Abraham [2018] carried out a study entitled A contrastive analysis of the use of conjunctions in English and Igala. The central objective of this study was to analyse the use of conjunctions in English and Igala, using the linguistic tool of contrastive analysis. As a qualitative study, data was collected based on a text of twenty-two English conjunctions (that comprised coordinating, subordinating and correlative conjunctions) which was produced in copies and distributed to some selected Igala informants for translation from English into Igala. The researcher used the translated text of conjunctions to read two books of the Igala Bible: the books of Jonah and James, and monitored the frequency of use of those conjunctions, as used in these books of the Igala Bible. The major findings of the study showed that: (i) the additive coordinating conjunction in Igala, kpài and, unlike in English, does not perform a linking function when it begins a sentence, according to the Igala Bible; (ii) conjunctions are actually many in Igala but it is just that few are used; (iii) there are more differences between the use of conjunctions in English and Igala than the similarities. The study's contributions to knowledge included its pedagogical or practical implications for the learners and teachers of the Igala language. The first task for teachers of Igala and Igala linguists in order to increase the use of more conjunctions in the language is to list all the conjunctions in English and translate them into Igala. After the translation exercise, the translated text should be carefully examined to ensure that it is devoid of any equivalent error. Then the new conjunctions should be added to the existing curriculum, and the teaching and learning of them could begin immediately in all the primary, secondary and tertiary institutions in Igala land where Igala language is taught as a subject or course.

\section{Theoretical Framework}

This study is anchored on the linguistic tool of contrastive analysis (CA) as propounded by Fries in 1945. According to Unubi (2018:45], the chief objective of CA is to examine the differences that subsist between languages as well as the difficulty they pose to L2 learners under teaching and learning situation. Consequent upon this, Fries [1945] as quoted by Lado [1957] which was reported in James [1980:148] declares that the most efficient materials are those based upon scientific description of the language to be learnt, carefully compared with a parallel description of the native language of the learner. Being a student of Fries, Lado [1957] as cited in James [1980:7] also followed through by supporting his master. He states that CA rests on the assumption that we can predict and describe the patterns [of L2] that will cause difficulty in learning, and those that will not cause difficulty, by comparing systematically the language and culture to be learnt with the native language and culture of the student. In the same vein, Filha [1997:5] quotes Hamp [1968] as saying that CA is basically the juxtaposing of accounts of two languages and the extraction of certain observation of learning difficulty. In view of the importance of CA in comparing two languages, Firbas [1992] as cited in Johansson [2008:9] comments that when we compare across languages, we can see the characteristics of each language more clearly, and the comparison can contribute to a better description of each individual language. 
Unubi, Sunday Abraham; A Contrastive Study of English and Igala Segmental Phonemes: Implications for ESL Teachers and Learners. Journal of Biomedical Engineering and Medical Imaging, Volume 6, No 6, December (2019), pp 31-43

Judging from the foregoing, it has become evident that no better framework fits this study than contrastive analysis (CA). This is so for two reasons: (i) this study juxtaposes the segmental phonemes of English and Igala to see the extent of differences and similarities between them, and (ii) the study aims to pin down the obvious difficulty or challenge that the differences in the segmental phonemes of both languages pose to the Igala learners and teachers of English (EFL). These, indeed, are the goal which contrastive analysis (CA) always seeks to achieve.

\section{Methodology}

This study, whose title is a contrastive analysis of English and Igala segmental phonemes: implications for EFL teachers and learners, resorts only to the secondary source of data. This way, data was drawn or collected from the archive of existing works in both languages. The data are in three divisions, namely: the consonants, vowels and diphthongs of both languages. The Igala orthography was obtained from the department of Igala Language and Culture, Kogi State College of Education Ankpa, in addition to other material in Igala. The consonant and vowel (including the diphthongs) phonemes of the two languages were juxtaposed or placed contiguously in a tabular form and given appropriate heading for easy observation of their level of differences and similarities by the researcher. Then words in which these phonemes occur in both English and Igala languages were supplied and the phonemes clearly indicated. From this outline, the researcher was able to pin down or predict the difficulty posed to both teachers and learners of English (EFL), who are of Igala extraction or ethnic origin. Of course, the input and intuitive insight of the researcher as a native speaker of the Igala language was also brought to bear on this work.

\section{Data Presentation and Analysis}

As pointed out earlier in our methodology, the data to be presented and analysed here are in three divisions. These include the consonants, vowels and diphthongs of both languages. They are juxtaposed or placed contiguously, presented in a tabular form, and labelled accordingly, as shown below:

Table 1: English and Igala Consonants

\begin{tabular}{|c|c|c|c|c|}
\hline $\begin{array}{c}\text { English } \\
\text { Consonants }\end{array}$ & $\begin{array}{c}\text { Word } \\
\text { found }\end{array}$ & $\begin{array}{c}\text { Igala } \\
\text { Consonants }\end{array}$ & $\begin{array}{c}\text { Word } \\
\text { found }\end{array}$ & Meaning \\
\hline $\mathrm{p}$ & pen & $\mathrm{p}$ & pọ & 'to peel' \\
\hline $\mathrm{b}$ & book & $\mathrm{b}$ & $\underline{\text { bó }}$ & 'to mould' \\
\hline $\mathrm{t}$ & test & $\mathrm{t}$ & $\underline{\text { tà }}$ & 'to sell' \\
\hline $\mathrm{d}$ & $\mathrm{den}$ & $\mathrm{d}$ & $\underline{\text { dó }}$ & 'to call' \\
\hline $\mathrm{k}$ & $\mathrm{keg}$ & $\mathrm{k}$ & $\underline{\text { kà }}$ & 'to say' \\
\hline $\mathrm{g}$ & gun & $\mathrm{g}$ & gà & 'to sew' \\
\hline- & - & $\mathrm{kp}$ & òkpò & 'fear' \\
\hline- & - & $\mathrm{gb}$ & ógbó & 'oldage' \\
\hline- & - & $\mathrm{ny}$ & ànyà & 'bicycle' \\
\hline- & - & $\mathrm{kw}$ & úkwú & 'death' \\
\hline- & - & $\mathrm{nw}$ & ínwâ & 'argument' \\
\hline- & - & $\mathrm{gw}$ & gwẹ & 'to wash' \\
\hline $\mathrm{f}$ & fish & $\mathrm{f}$ & òfi & 'to type of \\
& & & & fish' \\
\hline $\mathrm{v}$ & van & - & - & - \\
\hline$\theta$ & thorn & - & - & - \\
\hline$\delta$ & then & - & - & - \\
\hline $\mathrm{s}$ & sin & - & - & - \\
\hline
\end{tabular}




\begin{tabular}{|c|c|c|c|c|}
\hline z & zeal & - & - & - \\
\hline $\mathrm{s}$ & shaft & - & - & - \\
\hline 3 & measure & - & - & - \\
\hline $\mathrm{h}$ & hen & $\mathrm{h}$ & hì & 'to cook' \\
\hline $\mathrm{m}$ & moon & $\mathrm{m}$ & mú & 'to catch' \\
\hline 1 & leg & 1 & òlùlè & 'cricket' \\
\hline $\mathrm{n}$ & neck & $n$ & únû & 'tsetse fly' \\
\hline$r$ & room & $r$ & ùrà & 'enjoyment' \\
\hline$\eta$ & sing & $\mathrm{ng}$ & íngó & 'honey' \\
\hline j & yes & $\mathrm{j}$ & ùyò & 'joy' \\
\hline w & wound & $w$ & ìwò & 'pain' \\
\hline$t$ & church & t & ìchòchó & 'sponge' \\
\hline$d 3$ & judge & $d 3$ & ájá & 'market' \\
\hline
\end{tabular}

Table 2: English and Igala Vowels

\begin{tabular}{|c|c|c|c|c|}
\hline $\begin{array}{l}\text { English } \\
\text { Vowels }\end{array}$ & $\begin{array}{l}\text { Word } \\
\text { found }\end{array}$ & $\begin{array}{c}\text { Igala } \\
\text { Vowels }\end{array}$ & $\begin{array}{l}\text { Word } \\
\text { found }\end{array}$ & Meaning \\
\hline $\mathrm{i}$ & $\operatorname{tin}$ & $\mathrm{i}$ & İwá & 'dirt' \\
\hline $\mathrm{e}$ & bed & e & èlè & 'four' \\
\hline$æ$ & pack & $a$ & àtáá & 'father' \\
\hline $\mathrm{D}$ & dot & o & ódó & 'year' \\
\hline$\mho$ & book & $\mathrm{u}$ & ódú & 'name' \\
\hline$\Lambda$ & sun & - & - & - \\
\hline$\partial$ & above & - & $\ldots$ & \\
\hline i: & leak & i: & fíílí & 'narrow' \\
\hline $\mathrm{a}:$ & farm & a: & chákáá & 'all' \\
\hline ว: & law & ว: & piọolọ & 'pointed' \\
\hline u: & tool & u: & dúú & 'all' \\
\hline \multirow[t]{5}{*}{ 3: } & girl & ẹ: & èkwútéè & 'plenty' \\
\hline & & $\mathrm{e}$ & éle & 'gift' \\
\hline & & 0 & òdò & 'settlement' \\
\hline & & O: & òkóò & 'pig' \\
\hline & & e: & rèé & 'small' \\
\hline
\end{tabular}

Table 3: English and Igala Diphthongs

\begin{tabular}{|c|c|c|c|c|}
\hline $\begin{array}{c}\text { English } \\
\text { Diphthongs }\end{array}$ & $\begin{array}{l}\text { Word } \\
\text { found }\end{array}$ & $\begin{array}{c}\text { Igala } \\
\text { Diphthongs }\end{array}$ & $\begin{array}{l}\text { Word } \\
\text { found }\end{array}$ & Meaning \\
\hline іә & hear & - & - & \\
\hline еə & have & - & - & \\
\hline ஏə & poor & ua & àdua & 'prayer' \\
\hline ei & fame & ei & deida & 'transfigured' \\
\hline ai & line & ai & òwáílo & 'chameleon' \\
\hline ji & toy & गi & oidu & 'greeting name' \\
\hline əठ & foam & - & - & - \\
\hline$a \mho$ & loud & au & dáúdù & $\begin{array}{l}\text { 'greeting to an } \\
\text { older man' }\end{array}$ \\
\hline & & ia & lìa & 'come' \\
\hline & & iẹ & èbì̀̀ & 'blood' \\
\hline
\end{tabular}


Unubi, Sunday Abraham; A Contrastive Study of English and Igala Segmental Phonemes: Implications for ESL Teachers and Learners. Journal of Biomedical Engineering and Medical Imaging, Volume 6, No 6, December (2019), pp 31-43

\begin{tabular}{|c|c|c|c|c|}
\hline & & ie & èbie & 'seven' \\
\hline & & io & pioppio & 'quickly' \\
\hline & & iọ & ẹpio & 'mud' \\
\hline & & ou & òukwọ & 'grandfather' \\
\hline
\end{tabular}

\section{1 $\quad 6.1$ Analysing the data}

From table 1 above, we see that while English has twenty-four consonant phonemes, Igala has twentythree. As it is the case with other African languages, the dental fricatives $/ \theta /$ and $/ \delta /$ which are present in English are however absent in Igala, and as such, they are often substituted for the alveolar plosives / $t$ / and $/ d /$ respectively. Dialectically in Igala, $/ /$ and $/ r /$ are interchanged without altering the meaning. Thus in Ígala-mẹla, Idah, Òfù, Dekína and Ánkpa, lí 'to see', ilî 'root', óli 'tree', lùkókó 'bitter' are rí 'to see', ilî 'root', óri 'tree', rùkókó 'bitter' in Ògwùgwù. Similarly, /I/ and /j/ are also interchanged in some dialects of Igala without meaning difference, as in lí 'to see' in Ígala-mẹla, Idah, Òfù, Dekina and Ankpa is yí 'to see' in Ife. Furthermore, / $\mathrm{f} /$ and $/ \mathrm{h} /$ can be used interchangeably in Igala without any significant difference in meaning. For example in Ánkpa dialect, àhè 'shirt', òhù 'loss', àhù 'wind', ớhe 'title' (chieftaincy), etc. are àfẹ 'shirt', òfù 'loss', àfù 'wind', ơfẹ 'title' (chieftaincy) in Ígala-mẹla, Idah, Òfù, Dekina and Ánkpa dialects. These are never the case in English. The table also reveals that some English consonant phonemes such as $/ \delta /, / \theta /, / \mathrm{s} /, / \mathrm{J} /, / 3 /, / \mathrm{v} /$ and $/ \mathrm{z} /$ are absent in Igala, in just the same way the Igala consonant phonemes: /kp/, /gb/, /ny/, /kw/, /gw/ and /nw/ are absent in English.

From table 2, it is obvious that English has twelve pure vowels (monophthongs), while Igala has fourteen. Furthermore, some English vowel phonemes such as $/ \partial /$ and $/ \Lambda /$ are unavailable in Igala. On the other hand, some Igala vowel phonemes like /e/,/o/, /e:/ and /o:/ are not available in English. Also, notice that some English vowel phonemes are uniquely replaced in Igala as follows: /æ/ = /a/, /e/ = /ẹ/, /p/ = /o /, / / $=/ \mathrm{u} /$, and /3:/ = /e :/. Another difference is that vowel length in English can be tense and lax, as in been /bi:n/ and bin /bin/ but in Igala, it is lexical, as in du 'to carry' and dúú 'every', àchàká 'trousers' and chákáá 'all'.

From table 3, it is clearly evident that English has eight diphthongs whereas Igala has eleven. Then we see that the diphthongs such as /iə/, /eə/ and /əv/ which are available in English are however unavailable in Igala. Conversely, diphthongs like/ia/, /iẹ/, /ie/, /io/, /iọ/ and /ou/ which are present in Igala are however absent in English. Furthermore, notice that / $\mathrm{\sigma} /$ is represented by/ua/ in the Igala language.

One thing that is very noticeable from the three tables above is the fact that tone plays significant role on the vowel phonemes of the Igala language. Consequently, one Igala vowel sound can give different meanings to different words which can be distinguished only in writing through tone application. Thus, tá 'to winnow' or 'weave', tà 'to sell'; òkpò 'fear', Ókpo 'name of a place'; úkwú 'death', ùkwù 'smell'; etc. Lastly, differences and similarities in the segmental phonemes of both English and Igala languages are clearly shown by the tables as well as our analysis. And as such, we deem it unnecessary to outline or list them one after another.

\subsection{Implications for ESL Teachers and Learners}

As far as the teaching and learning of English by Africans is concerned, it is practically impossible to rule out the role or influence of mother-tongue or L1 on L2. Therefore, it becomes imperative to use this study as a medium to emphasize this influence to the Igala teachers and learners, especially due to the obvious 
fact that whatever a learner hears or sees from the teacher in the new language, it is usually indelibly imprinted or registered on his/her mind. From zero level, the learner begins the task of learning L2, steadily accumulates knowledge day-in-day-out, and gets to the zenith by way of proficiency in the use of the language. Now for the successful achievement of this goal, the role of the teacher cannot be underestimated. That is why the implications of this study capture both ESL teachers and learners.

Owing to this reason, certain phonological errors are bound to occur both in the lgala teacher and learner, most especially as some of the English sounds are not available in the Igala language, according to the data presented and the analysis offered in this study. To this end, due to the reason that the English consonant phonemes such as $/ \delta /, / \theta /, / \mathrm{s} /, / \mathrm{J} /, / 3 /, / \mathrm{v} /$ and $/ \mathrm{z} /$ are not present in Igala, many Igala teachers and learners find it extremely difficult to pronounce them. For example, the Igala learner realises $/ z /$ and $/ 3 /$ as $/ \mathrm{d} 3 /$, and $/ \mathrm{J} / \mathrm{as} / \mathrm{t} /$ since these are what he/she has in his/her language. Thus zeal or Zaria is /dzi:I/ and /dzaria/ respectively; measure or treasure is /metjə/ and /tretfə/ respectively, among others. Similarly, the voiceless dental fricative $/ \theta /$ is often realised as the voiceless alveolar plosive $/ t /$, while the voiced dental fricative $/ \delta /$ is also substituted for the voiced alveolar plosive /d/. Thus thing / $\theta \mathrm{in} / \mathrm{is} / \mathrm{tin} / \mathrm{while}$ then /ðen/ is /den/. In the case of the vowel phonemes, since /ə/ and / $\Lambda$ are not available in Igala, the learner articulates cup /kıp/ as /kọp/, and stresses the unstressed schwa in doctor /dpktə/ as /dpktọ/. Notice that some of these issues, especially the last three are not peculiar to the Igala language only but also to the majority of the Nigerian speakers of English. We deliberately included teachers in this study because these observed differences could also pose a challenge to them. Imagine a teacher who has not worked on himself/herself to overcome this phonological challenge, he/she would pass it on to the learner, and this can be misleading to him or her (learner). Therefore, both teachers and learners should work on themselves to overcome this difficulty. To do this, they should be acquainted with the sound systems of both languages, see the areas of differences, mark the challenge this differences pose to them, and devise a means, perhaps, by constant drilling and consciousness to overcome the challenge.

\subsection{Research Findings}

From the data collected, presented and analysed above, the following are the findings of this research: (i) English has twenty-four consonant phonemes while Igala has twenty-three; (ii) In some dialects of Igala, $/ / /$ and / $r /$ are interchanged without altering the meaning. Thus in Ígala-mẹla, Idah, Òfù, Dekina and Ánkpa, lí 'to see', ólí 'tree' are rí 'to see' and órí 'tree' in Ògwùgwù. Similarly, /// and / j/ are also interchanged without meaning difference, as in lí 'to see' in Ígala-mẹla, Idah, Òfù, Dekina and Ánkpa is yí 'to see' in Ife; (iii) English consonant phonemes such as $/ \delta /, / \theta /, / \mathrm{s} /, / \mathrm{J} /, / 3 /, / \mathrm{v} /$ and $/ \mathrm{z} /$ are absent in Igala, in just the same way the Igala consonant phonemes: /kp/, /gb/, /ny/, /kw/, /gw/ and /nw/ are absent in English; (iv) English has twelve pure vowels (monophthongs) and eight diphthongs, while Igala has fourteen monophthongs and eleven diphthongs; ( $v$ ) diphthongs such as /iə/, /eə/ and /əv/ which are available in English are however unavailable in Igala. Conversely, diphthongs like /ia/, /iẹ/, /ie/, /io/, /iọ/ and /ou/ which are present in Igala are however absent in English; (vi) some English vowel phonemes are uniquely replaced in Igala as follows: /æ/ =/a/, /e/ =/ẹ/, /p/ =/o/, / / / / / /, and /3:/ = /ẹ:/; and (vii) vowel length in English can be tense and lax, as in been /bi:n/ and bin /bin/ but in Igala, it is lexical, as in $d u$ 'to carry' and dúú 'every', àchàká 'trousers' and chákáá 'all'. 
Unubi, Sunday Abraham; A Contrastive Study of English and Igala Segmental Phonemes: Implications for ESL Teachers and Learners. Journal of Biomedical Engineering and Medical Imaging, Volume 6, No 6, December (2019), pp 31-43

\section{Conclusion}

The researcher, in this work, no doubt, has made an attempt on the subject matter. In the study, the writer uses the framework of contrastive analysis as a tool to compare the segmental phonemes of both languages. From the data collected, presented and analysed, it is a fact that there exist differences and similarities in the segmental phonemes of both English and Igala. Moreover, from the comparison, a reasonable number of findings have been recorded. In addition, the existing differences noticed from the study have posed teaching and learning difficulty phonologically to both Igala teachers and learners of English (ESL), a situation referred to as mother-tongue interference in education. The study closes by offering a piece of advice to both ESL teachers and learners who are of Igala extraction to work on themselves to enable them to overcome the difficulty, especially the teachers, in order not to mislead the learners. Both of them could do this by getting themselves acquainted with the sound systems of both languages, see the areas of differences, mark the challenge this differences pose to them, and devise a means, perhaps, by constant drilling to overcome the challenge.

\section{CONTRIBUTION TO KNOWLEDGE}

Undoubtedly, as one carefully considers the findings of this research, which emanated from the data collected, presented and analysed, it is never an overstatement to say that, as far as the discipline of linguistics is concerned, this study has contributed to knowledge. As the reader looks at the study, most especially the presentation of data and analysis, its voice in contributing to knowledge is very loud. Furthermore, the implications of the study, in which the researcher laid bare before the readership the various areas that constitute or pose teaching and learning difficulty to both Igala teachers and learners as well as its findings as indicated above, is one of the immense and unique contributions of the study to knowledge. Furthermore, as one looks at the entire outline of this research from abstract to conclusion, making this study available in the field of language study, which will definitely serve as a guide or template to both students and scholars who would like to conduct similar studies in other indigenous languages of Nigeria, is nothing more than a contribution to knowledge.

\section{RECOMMENDATIONS FOR FURTHER STUDIES}

In spite of the existing studies in English and Igala phonetics and phonology, this specific aspect, which is a contrastive study of English and Igala segmental phonemes: implications for ESL teachers and learners, can open floor for more researches to the academic community of linguists, especially a contrastive study of this kind between English and any Nigerian language, or between two Nigerian languages. As a matter of fact, undergraduate and graduate students as well as scholars in English and general linguistics can use this research as a guide to carry out more researches into such areas as: a contrastive study of English and Nupe, Ebira (any Nigerian language) segmental phonemes: implications for ESL teachers and learners, a comparative analysis of Igala and Yoruba segmental phonemes, a comparison of Igala and Idoma phonemic sounds, etc. Indeed, this study can be replicated in many languages of the world. 


\section{REFERENCES}

[1] Aluke, David Juliet. 2017. The realisation of stative and dynamic verbs in Nigerian English. Jos: University of Jos. Unpublished MA Dissertation.

[2] Bittner, M.A. 2013. Allophonic variation in English: Phoneme versus allophone. Phonetics and Phonology 2, Spring Online: www.academia.edu/5330501/Allophonic Variation in English Phoneme vs. Allophone, accessed October 30, 2018.

[3] Crystal, David. 1991. A dictionary of linguistics and phonetics. Oxford: Blackwell Publishers.

[4] Dresher, Elan B. 2008. The phoneme. Online: http://www.companiontophonology.com/fragr image/phoneme, accessed October 30, 2018.

[5] Edimeh, Francis Ohiemi. 2006. The legacies of Atta Ayegba Om'ldoko: A concise history of Igala land. 1. CUCA Communications.

[6] James, Carl. 1980. Contrastive analysis. London: Longman.

[7] Johannson, Stig. 2008. Contrastive analysis and learner language: A corpus-based approach. University of Oslo. Online: uio.no/ilos/forskning/grupper/Corpus_Linguistics_and_English_Language/papers/contras tiveanalysis-and-learner-language_learner-language-part.pdf, accessed May 16, 2019.

[8] Jowitt, David. 2009. English language and literature in historical context. Jos: Spectrum Books Limited.

[9] Kopečna, P. 2008. Contrastive linguistics and contrastive analysis. Zech Republic: Masaryk University. PhD Thesis. Online: https://is.muni.cz/th/qx7ir/Thesis 2nd draft.pdf, accessed October 29, 2018.

[10] Malah, Zubairu, and Rashid, Sebariah Md. 2015. Contrastive analysis of the segmental phonemes of English and Hausa languages. International Journal of Languages, Literature and Linguistics 1, 2. 106112.

[11] Moore, Andrew. 2001. Phonology. Online: http://www.shunsley.eril.net/armoore/, accessed October 30, 2018.

[12] Mugair, Sarab Kadir, and Mahadi, Tengku Sepora Tengku. 2014. A contrastive analysis of vowel sounds in English and Arabic Languages. Journal of Harmonized Research in Applied Sciences (JOHR) 2, 3. 178183.

[13] Nwabudike, Christopher Eziafa, Kaan, Aondover Theophilus and Anaso, George Nworah. 2015. A contrastive analysis of English and Tiv segmental phonemes: Implications in ESL Learning. International Journal of Innovative Literature, Language \& Arts Studies 3, 4. 1-6.

[14] Roach, Peter. 2009. English phonetics and phonology glossary (A little encyclopedia). Online: https://www.ff.umb.sk/app/cmsFile.php?disposition=a\&ID=14179, accessed October 30, 2018. 
Unubi, Sunday Abraham; A Contrastive Study of English and Igala Segmental Phonemes: Implications for ESL Teachers and Learners. Journal of Biomedical Engineering and Medical Imaging, Volume 6, No 6, December (2019), pp 31-43

[15] Szczegielniak, Adam. 2001. Introduction to linguistic theory - Phonology: The sound patterns of language. Online: https://scholar.harvard.edu/files/adam/files/phonology.ppt.pdf, October 30, 2018.

[16] Unubi, Sunday Abraham. 2018b. A contrastive analysis of the use of conjunctions in English and Igala. M.A. Dissertation. University of Jos. Germany: LAP LAMBERT Academic Publishing.

[17] Unubi, Sunday Abraham, and Yusuf, Sadiya. 2017. Fundamental linguistic information on English, Igala and Hausa languages. World Wide Journal of Multidisciplinary Research and Development 3, 12, 409419.

[18] Unubi, Sunday Abraham, and Bello, Ebunlomo Comfort. 2019. Essential linguistic knowledge on French and English languages. Global Journal of Applied, Management and Social Sciences 16, 52-66. 